\title{
Latest Santonian to latest Maastrichtian planktic foraminifera and biostratigraphy of the hemipelagic successions of the Prebetic Zone (Murcia and Alicante provinces, south-east Spain)
}

\author{
B. Chacón ${ }^{\mathrm{a}, *}$, J. Martín-Chivelet ${ }^{\mathrm{a}}$, K.-U. Gräfe ${ }^{\mathrm{b}}$ \\ ${ }^{a}$ Departamento de Estratigrafia, Instituto de Geologia Económica (CSIC-UCM), 28040 Madrid, Spain \\ ${ }^{\mathrm{b}}$ Department of Geosciences, University of Bremen, PO Box 330440, D-28334 Bremen, Germany
}

\begin{abstract}
This paper presents the first detailed biostratigraphic analysis of the uppermost Santonian through uppermost Maastrichtian hemipelagic carbonate successions of south-east Spain based mainly on the stratigraphic distributions of planktic foraminifera. For the time interval studied, seven biozones of planktic foraminifera have been recognized. From oldest to youngest these are: the uppermost part of the Dicarinella asymetrica Zone, and the Globotruncanita elevata, Globotruncana ventricosa, Globotruncanita calcarata, Globotruncana falsostuarti, Gansserina gansseri and Abathomphalus mayaroensis zones. The biostratigraphic succession obtained from the sections studied in the Prebetic area is compared with those from sections in Tercis (France) and Kalaat Senan (Tunisia).
\end{abstract}

Keywords: Planktic foraminifera; Biostratigraphy; Hemipelagic; Campanian; Maastrichtian; Betic Ranges; Spain

\section{Introduction}

The aim of this paper is to present a detailed biostratigraphy, based primarily on planktic foraminifera, of the late Santonian-late Maastrichtian hemipelagic successions that crop out in the Prebetic Zone of south-east Spain. This southernmost region is a key area for interbasinal correlations and palaeobiogeographic reconstructions within the framework of the Tethys Realm. At the end of the Cretaceous, the convergence of Africa and Eurasia had begun, causing progressive closure of many small basins in western Europe and northern Africa, and the restriction of marine

\footnotetext{
* Corresponding author.

E-mail addresses: bchacon@,geo.ucm.es (B. Chacón), j.m.chivelet@ geo.ucm.es (J. Martín-Chivelet), ugraefe@micropal.uni-bremen.de (K.-U. Gräfe).
}

communication between the Tethys and the Atlantic to the so-called Gibraltar Passage. These successions were deposited in the outer domains of the ancient southern continental margin of Iberia (Fig. 1), a basin that, during the latest Cretaceous, formed the southernmost area of the northern margin of the Tethys Ocean.

Recent biostratigraphic work on both the north-east Atlantic margin (e.g., Arz and Molina, 2001; Odin, 2001) and the southern Tethys margin (e.g., Robaszynski et al., 2000) has revealed notable differences in the chronostratigraphic distribution of species commonly used as global biostratigraphic markers. We present here the stratigraphic distribution of these taxa in a zone that occupied an intermediate palaeogeographical situation between the reference section for the CampanianMaastrichtian boundary at Tercis in south-west France and the Kalaat Senan section in Tunisia, which provides abundant information about the North African Upper Cretaceous. 


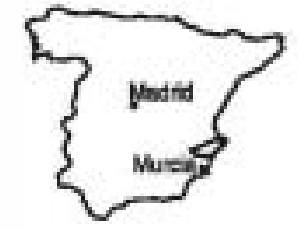

\section{Exposures studied:}

1. C. Cachorro (5^ Carche) 1a, Respay (S॰ Carche)

2. Malgmo

3. Abcorta

4 JIJona I

4b, JJjona II

4c, Busol

4d, Torremanzanas

5. Aguas de Busot

6. Aspo

* Other sections studled

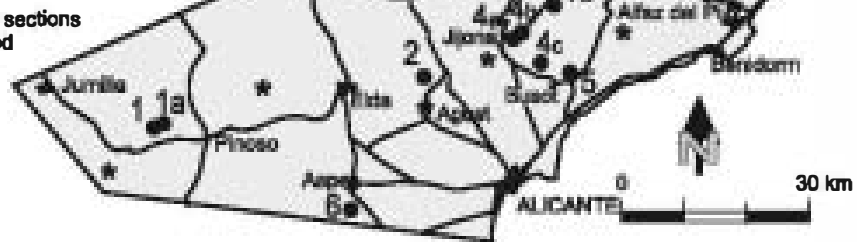

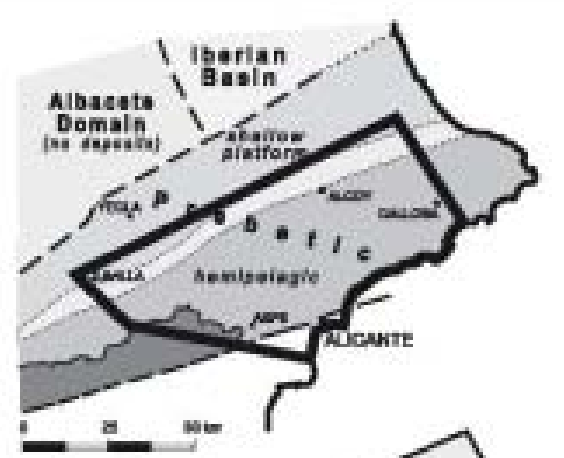

a $\quad 06$

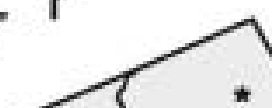

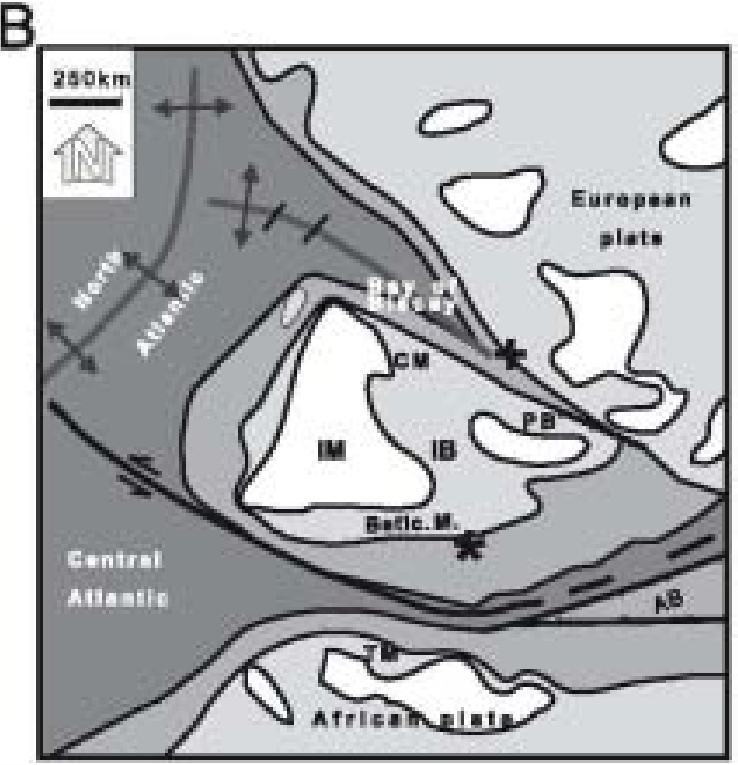

Positive areas (anorogenic)

Shallow marine envionments

Deeper marine environments

Oceanic / suboceanic crust

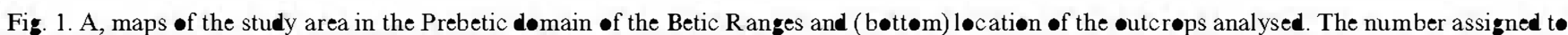

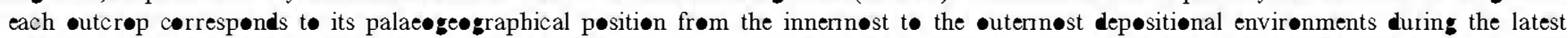

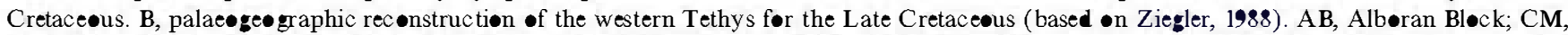
Cantabrian Margin; IB, Iberian Basin; IM, Iberian Massif; PB, Pyrenean Basin; TM, Tellian Margin. Apprøximate løcatiøns of the study area ( and Tercis (+).

Furthermore, on a regional scale, our biostratigraphic analysis allows the establishment, for the first time, of detailed intrabasinal correlations and the recognition of a series of regional unconformities. These define major and rapid palaeogeographic changes that punctuated the evolution of the basin during the Late Cretaceous.

\section{Geographical and geological setting}

During the Late Cretaceous, the southern part of Iberia consisted of a broad continental margin (the Betic margin) characterized by the dominance of carbonate sedimentation in both the shallow areas, where wide carbonate platforms developed, and the deeper domains, where thick, relatively homogeneous, hemipelagic successions were deposited. According to previous studies on the shallow carbonate platforms (e.g., Martín-Chivelet, 1995, 1996), sedimentation on the margin was mainly controlled by thermal subsidence, a warm climate and sea-level changes. This sedimentation was also punctuated, however, by a series of tectonic events that caused abrupt changes in palaeogeography, which could be related to intraplate stresses during the initiation of Europe-Africa alpine convergence.
During the latest Santonian-latest Maastrichtian interval, thick, relatively homogeneous, carbonate hemipelagic successions were deposited in the proximal, relatively deep, marine environments of the continental margin. These deposits crop out today in the southeastern part of the Prebetic Zone, in the provinces of Alicante and Murcia (Fig. 1). This area of great tectonic complexity forms part of the autochthonous to parautochthonous units that define the most external belt of the alpine Betic Orogen.

The hemipelagic deposits studied form successions $15-140 \mathrm{~m}$ thick consisting primarily of limestones and marly limestones and, to a minor extent, of marls. In previous regional studies, these deposits were included, because of their relative lithological homogeneity, in broad cartographic units that embodied the whole of the Upper Cretaceous and Palaeocene succession (e.g., the "Capas Rojas" of Vera et al., 1982). However, recent detailed research that forms part of the broad regional project in which this study is included, is allowing the subdivision of these deposits into smaller and more useful lithological units, most of which are bounded by unconformities. In this sense, the uppermost Santonian-Maastrichtian rocks have been subdivided into three formations: Carche, Raspay and Aspe. The Carche and Raspay formations were defined 
by Martín-Chivelet (1994), whereas the Aspe Formation has been proposed by Chacón and Martín-Chivelet (in press).

The Carche Formation, of latest Santonian-early Maastrichtian age, is 7 to $>100 \mathrm{~m}$ thick and basically consists of light-coloured, often burrowed, limestones and marly limestones, commonly stratified in beds $0.1-0.2 \mathrm{~m}$ thick, and yield abundant inoceramids and echinoids. It crops out in the north-western part of the study area, which palaeogeographically corresponds to the shallowest hemipelagic settings of the basin.

Laterally and basinwards, the Carche Formation grades into the Aspe Formation, which has been dated as earliest Campanian-early Maastrichtian. The Aspe Formation is similar in thickness to the former but consists of markedly rhythmic successions with alternations of white, pink and red limestones and marls. Both formations form jointly a major allostratigraphic unit, bounded by regional unconformities or, occasionally, by their correlative conformities. The Aspe Formation rests on deposits ranging in age from mid Cenomanian to late Santonian, and is overlain by the deposits of the Raspay Formation.

The Raspay Formation is late Maastrichtian in age and mainly composed of massive, green to grey marls with abundant planktic and deep-water benthic foraminifera, ostracods, and remains of inoceramids and echinoids. To a lesser extent, decimetre-scale beds of fine-grained wackestones and packstones with the same fossil content can be also present in the formation. In some sections turbidite intercalations and other gravity deposits have been recognized. The Raspay Formation extends over the whole of the area studied and forms a major allostratigraphic unit that rests unconformably on the Carche and Aspe, and older formations. It is overlain in the study area by early Palaeocene or younger rocks.

\section{Stratigraphic analysis}

Owing to the considerable variations in thickness, completeness, and facies shown by the uppermost Santonian-uppermost Maastrichtian deposits in the study area, our paper is based on an integrated analysis of several outcrops. Ten stratigraphic sections and 10 other smaller outcrops distributed all over the area have been analysed and correlated (Fig. 2). In order to simplify discussion, these sections have been grouped, according to their geographical proximity and their stratigraphic affinities, into six main areas, namely (Fig. 1): Sierra del Carche, Sierra del Maigmó, Sierra de Aixorta, Jijona-Busot-Torremanzanas, Aguas de Busot, and Aspe. The order in which these areas are described below broadly follows a proximal-distal palaeogeographic trend in the basin. Water-depths for these areas show minor variations that do not necessarily correspond to this trend.

The biostratigraphic analysis is concentrated on planktic foraminifera (Figs. 3 and 4), and is based on both thin sections and washed residues. It has been accompanied by a detailed sedimentological study of facies and stratigraphic unconformities. In terms of biostratigraphy and dating, we essentially follow the papers of Robaszynski et al. (1984, 2000), Caron (1985), Robaszynski and Caron (1995), Premoli Silva and Sliter (1995), and Hardenbol et al. (1998).

\subsection{Sierra del Carche}

The uppermost Santonian-uppermost Maastrichtian succession presents excellent outcrops in the southeastern part of the Sierra del Carche (Fig. 1), where the type locality of the Carche and Raspay formations (Martín-Chivelet, 1994) is located. Previous papers on the Upper Cretaceous of this sierra can be found in Azéma (1977), Rodríguez Estrella et al. (1980) and Martín-Chivelet (1992).

The Carche Formation is $60 \mathrm{~m}$ thick and consists predominantly of white to beige limestones and marly limestones in beds $0.1-0.2 \mathrm{~m}$ thick. It rests on Middle Cenomanian shallow water carbonates of the Alatoz Formation (Martín-Chivelet, 1992) and its upper boundary is marked by a poorly developed ferruginous crust. The main facies of the unit are: (1) beige wackestones with abundant planktic and benthic foraminifera, ostracods and calcispheres; (2) fine-grained packstones, with remains of these microfossils and abundant fragments of inoceramids and echinoids; and (3) white marly wackestones to marls. All the rocks are strongly burrowed, and yield abundant inoceramids and echinoids, and also some ammonoids. The unit is interpreted as having been deposited in hemipelagic settings of an outer, relatively shallow platform, with a limited influx of fine clastics. The presence of fine-grained, well-sorted packstones suggests that the sea floor was probably affected by bottom currents.

Our biostratigraphic analysis has allowed recognition of the following planktic foraminiferal biozones in the Carche Formation. These are, from base to top: the uppermost part of the Dicarinella asymetrica Zone, the Globøtruncanita elevata, Globøtruncana ven-

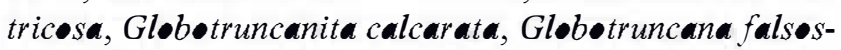
tuarti zones, and the lower part of Gansserina gamsseri Zone (Fig. 5). Accordingly, the Carche Formation in this section is latest Santonian (early Campanian)-early Maastrichtian in age.

The Raspay Formation is $12.5 \mathrm{~m}$ thick and composed of distinctly olive green marls, although its top is defined by $0.7-1.2 \mathrm{~m}$ of beige to white, nodular biomicrites. On 
Sections studied

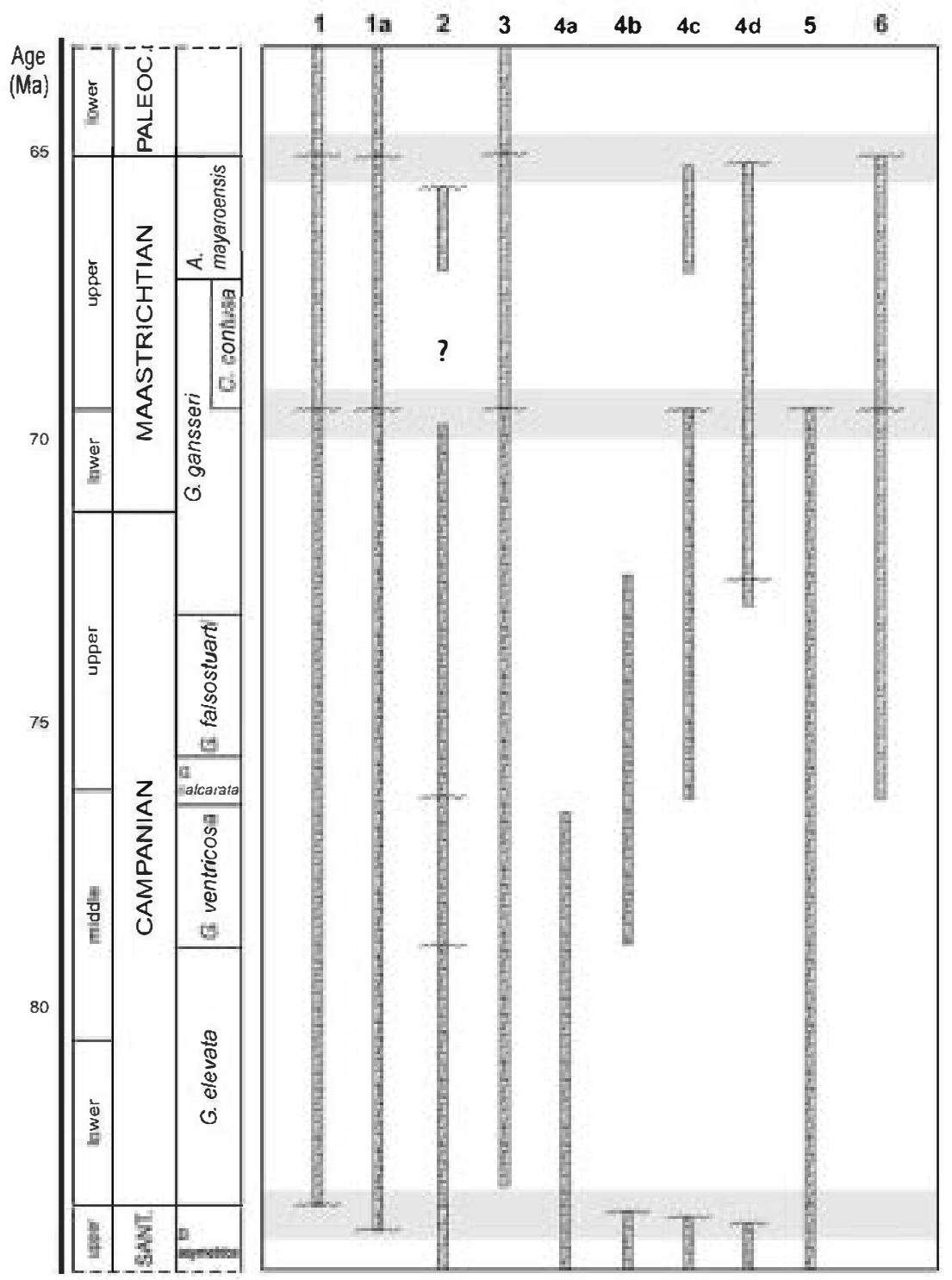

Fig. 2. Biøchrøstratigraphic chart shøing the time intervals analysed and the reconized unconformities in each sectiøn. The numbers at the tøp

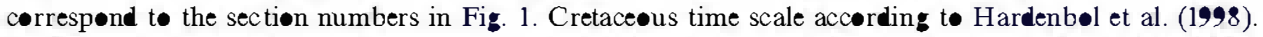

this uppermost level there is an intensively mineralised and bored hardground, with abundant epibenthonic fauna. This hardground is overlain by white limestones that have been dated as early (but not earliest) Palaeocene (Chacón, 2002). The marls have yielded abundant planktic and deep-water benthic foraminifera, ostracods, and remains of inoceramids and echinoids. The unit is interpreted as having been deposited in an outer, relatively deep (outer neritic to bathyal) platform with a large terrigenous influx.

The planktic foraminifera of the Raspay Formation (Fig. 5) have allowed the identification of the upper part of the Gansserina gansseri Zone and the Abathomphalus mayaroensis Interval Zone. These allow the unit to be dated as late Maastrichtian.

\subsection{Sierra del Maigmó}

The section studied is situated on the northern slope of the Sierra del Maigmó, in El Estrecho creek. The exposure includes an excellent section of the Carche Formation and only a partial section of the Raspay Formation. The former overlies white limestones of Santonian age, the contact between them apparently being gradual, and defined by a rapid increase in the content of fine siliciclastic sediment in the succession. Its upper boundary is, however, covered and could not be studied. The top of the section is marked by an unconformity that separates the upper Maastrichtian rocks of the Raspay Formation from overlying marly deposits of latest Palaeocene-early Eocene age. 

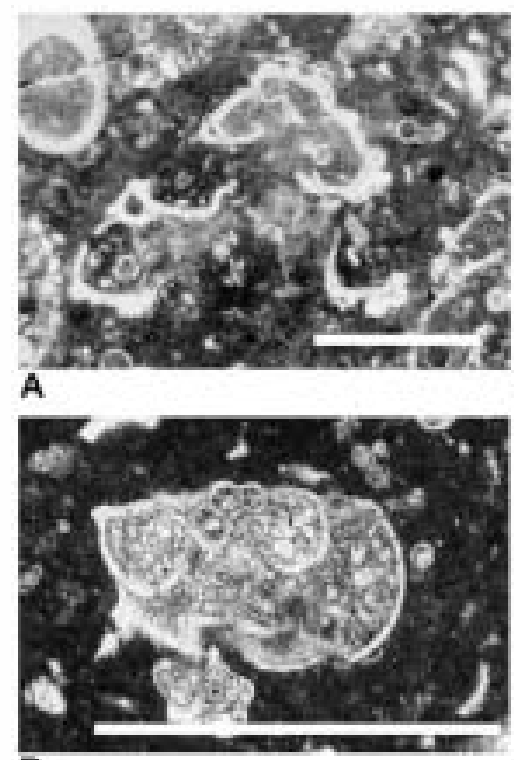

D

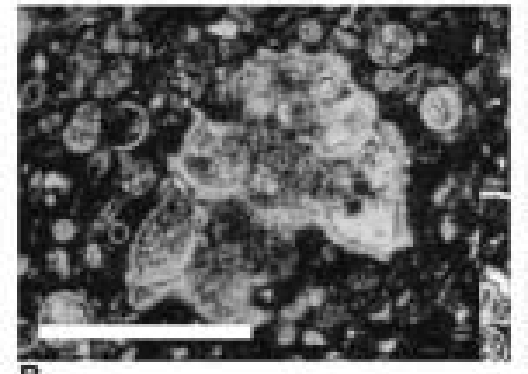

B
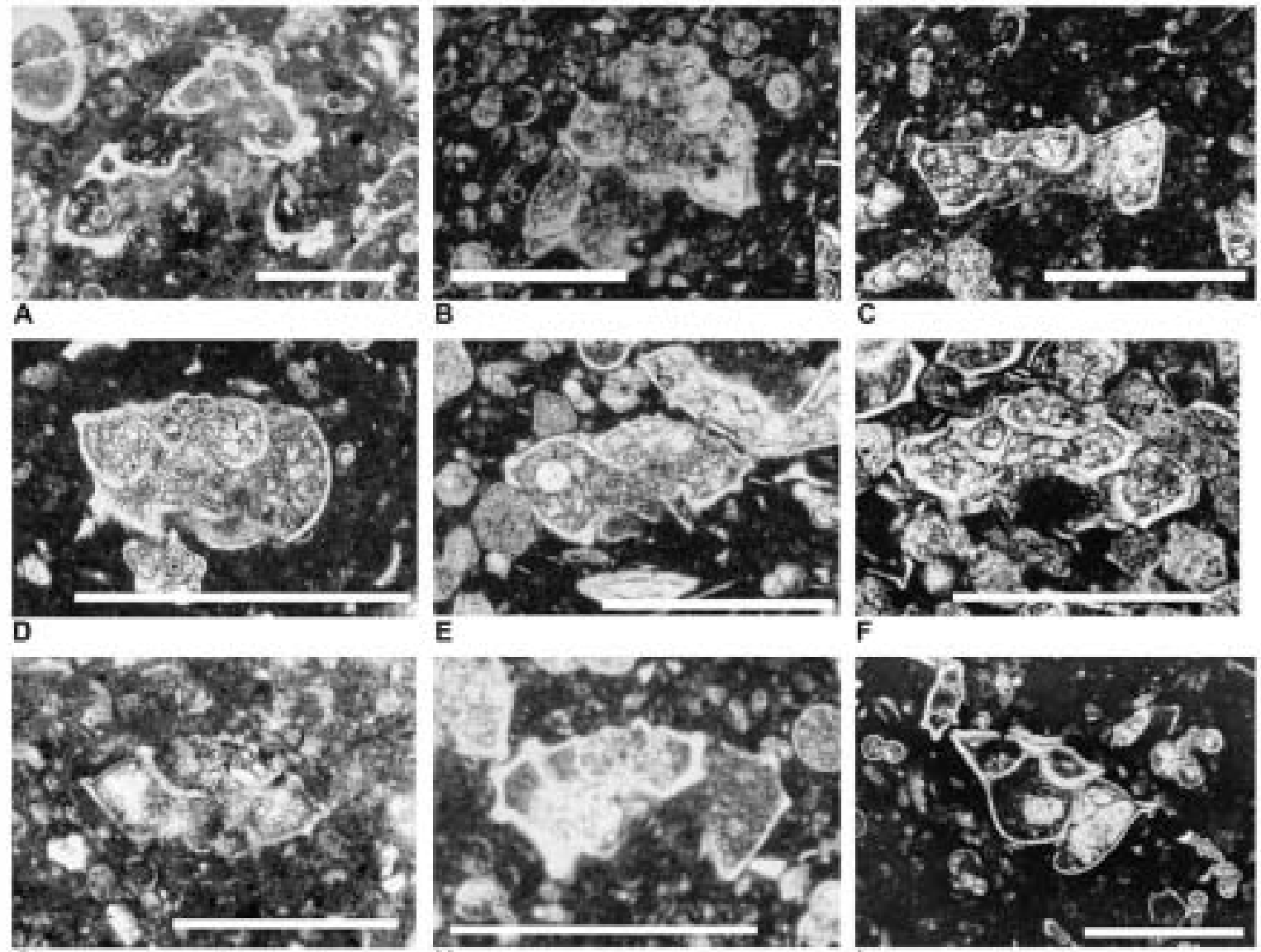

G
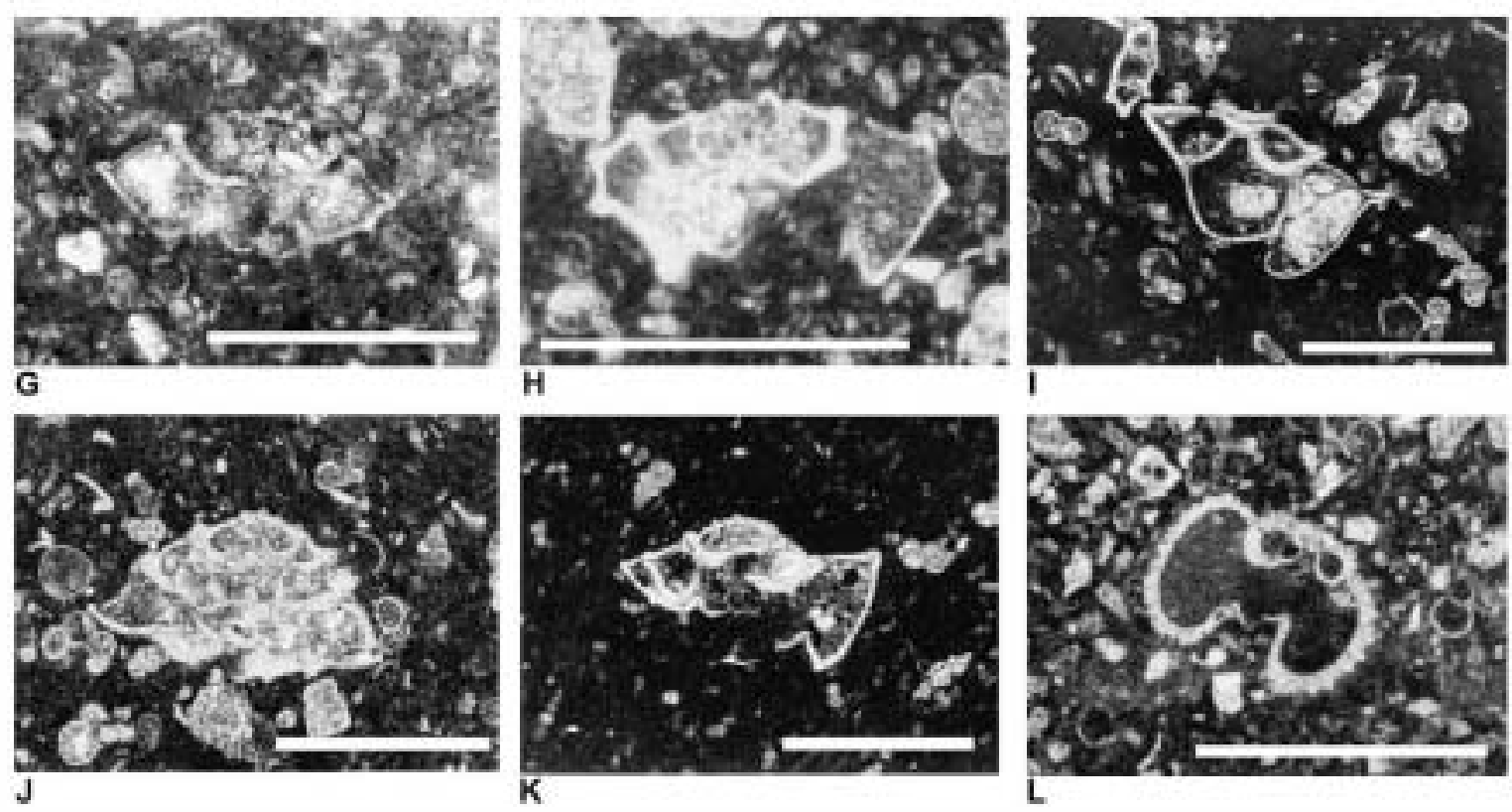

I

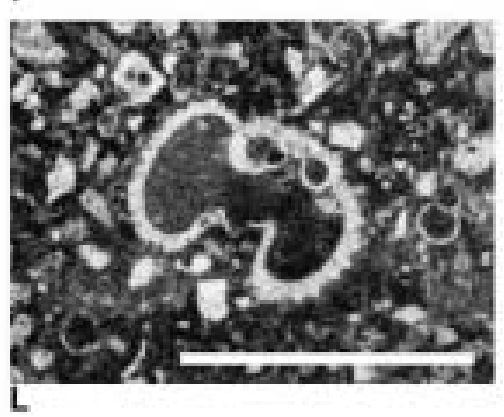

Fig. 3. Planktic foraminifera in thin section. A, Contusotruncana contusa (Cushman, 1926), Sierra del Carche, sample CAR 35. B, Contusotruncana

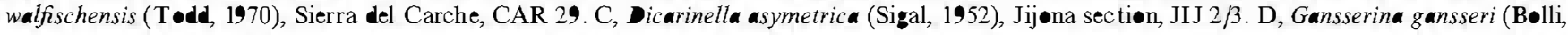
1951), Aspe section, ASP 19. E, Globotruncana aegyptiaca (Nakkadi, 1950), T•rremanzanas, PIL 7/1. F, Globotruncana arca (Cushman, 1926), T•rremanzanas, PIL 5/2. G, Globotruncan falsostuarti (Sigal, 1952), Sierra del Carche, RAS I. H, Globotruncana ventricosa (White, 1928), Sierra de Aix orta, ALX 51. I, Globotruncanita calcarata (Cushman, 1927), Aspe sectiøn, ASP 4. J, Globotruncanita conica (White, 1928), Aspe sectiøn, ASP 23a. K, Globotruncanita elevata (Brøtzen, 1934), Jijøna section, JIJ 4/5. L, Rugoglobigerina rotundata (Brönnimann, 1952), Sierra del Carche, CAR 37a. Scale bars represent $0.5 \mathrm{~mm}$.

Previous stratigraphic work on the Sierra del Maigmó can be found in the publications of Leclerc (1971) and Ruig (1992).

The Carche Formation is $105 \mathrm{~m}$ thick and basically consists of thinly stratified limestones and marls in beds $0.1-0.3 \mathrm{~m}$ thick that show variable bioturbation although this is generally less intense than that in the Sierra del Carche. The section is punctuated by several truncation surfaces (slump scars), brecciated levels and slumps. Main facies include fine-grained wackestonespackstones with a variable content of fine siliciclastics, and marly limestones to marls. These facies contain abundant planktic and deep-water benthic foraminifera, calcispheres, and debris of inoceramids and echinoids. The unit was probably deposited in a transitional setting between the most external platform and deeper environments. The benthic foraminiferal assemblage, which contains Cibicidoides velascoensis (Cushman, 1925), 


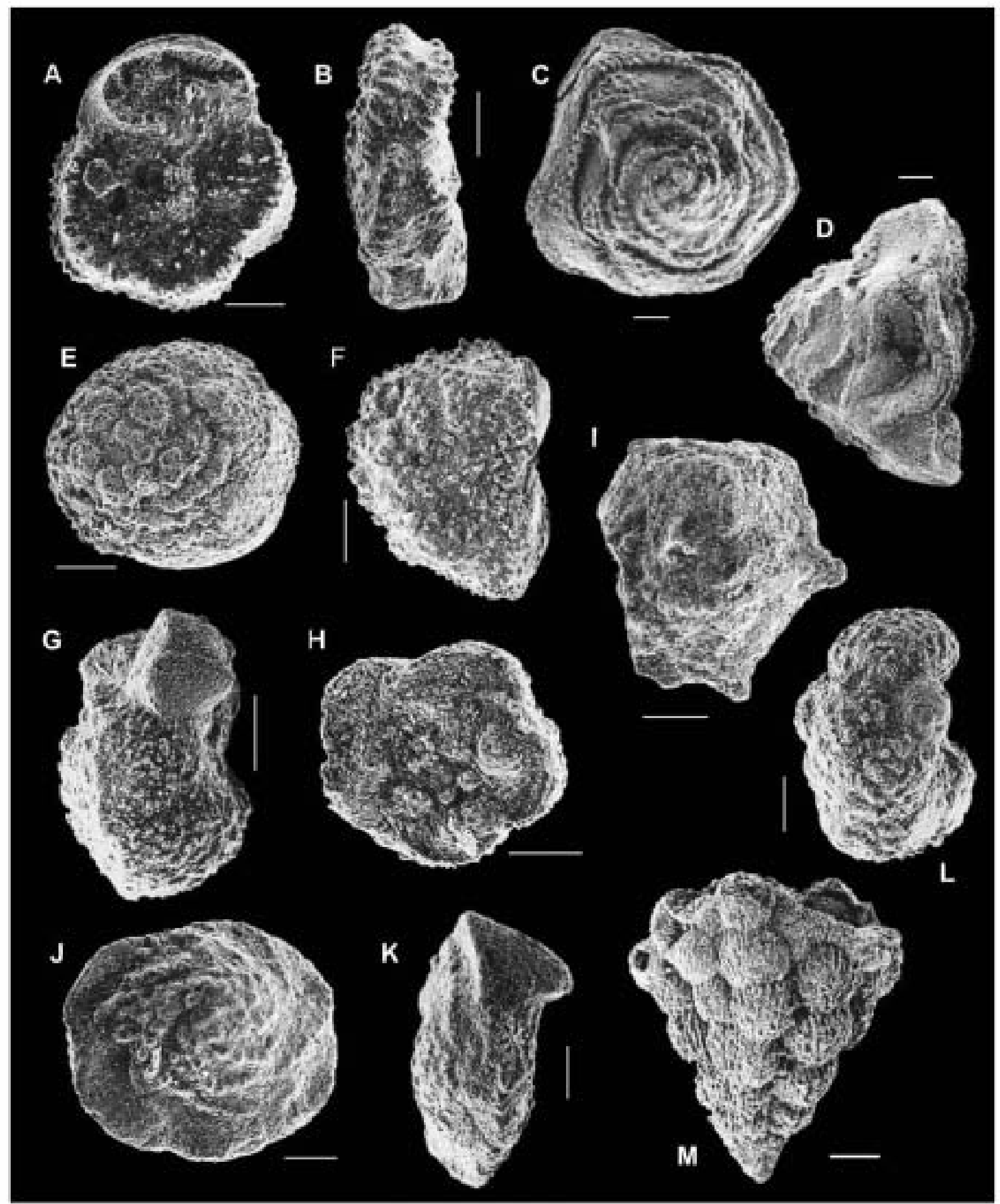

Fig. 4. SEM (scanning electrøn micrescope) images of planktic foraminifera. A, B, Abathomphalus mayaroensis (Bølli, 1951). A, umbilical view; B, side view; Aspe section. C, D, Contusotruncan contusa (Cushman, 1926). C, spiral view; D, side view; Sierra del Carche. E, F, Contusotruncana

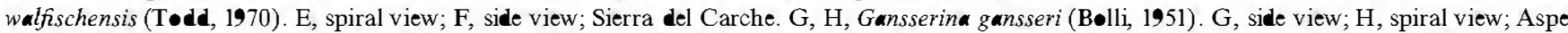
section. I, Globotruncanita calcarata (Cushman, 1927), umbilical view; Sierra del Maigmi. J, K, Globotruncanita elevata (Brotzen, 1934). J, spiral view; K, side view; Sierra del Maigmó. L, Rugoglobigerina rugosa (Plummer, 1926), side view; Aspe section. M, Racemiguembelina fructicosa (Egger, 1899), frønt view; Sierra del Carche. Scale bars represent $100 \mu \mathrm{m}$ 


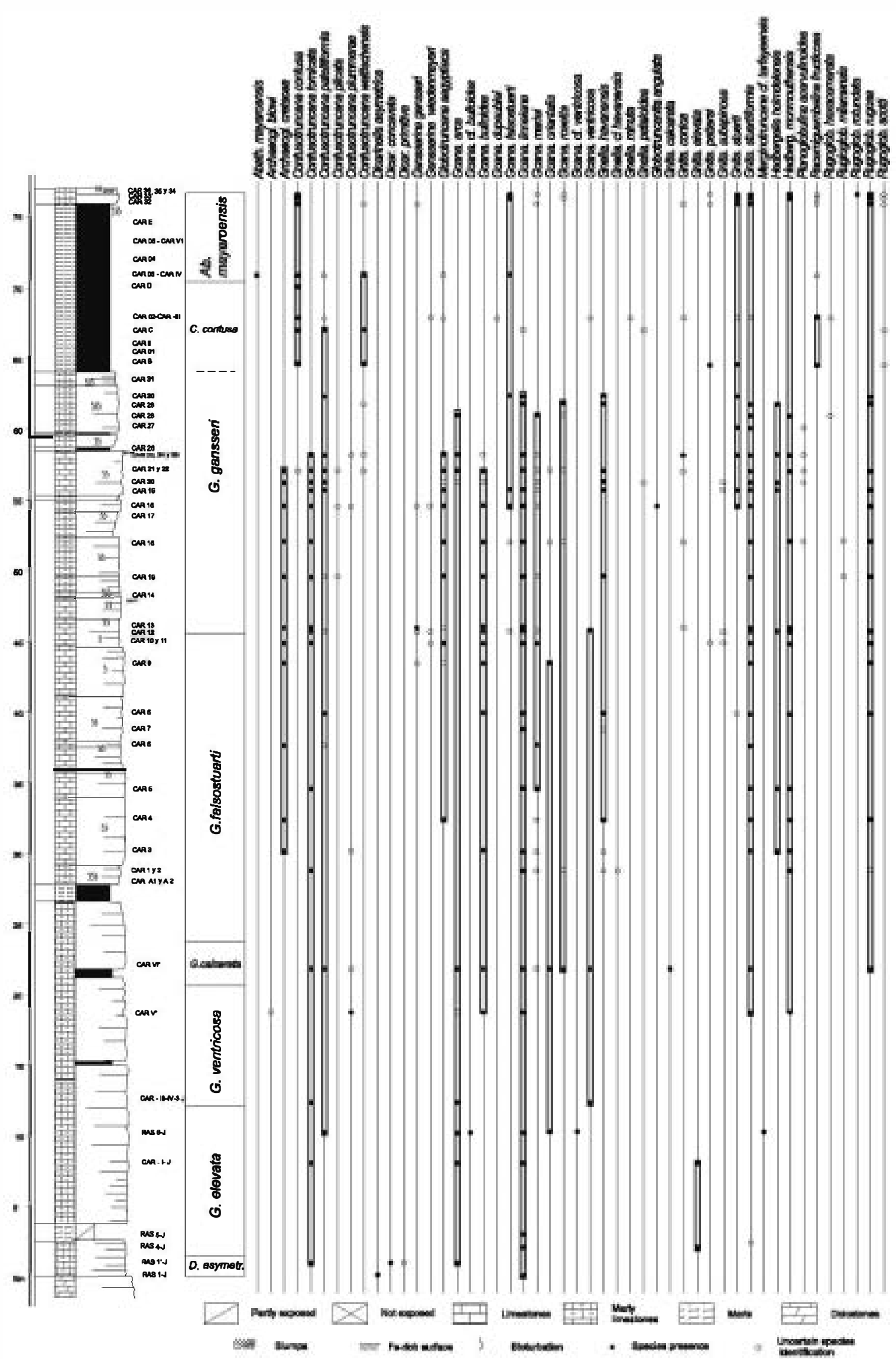

Fig. 5. General biestratigraphic chart with ranges of the planktic foraminifera in the Sierra del Carche. 
Coryphostoma incrassata (Reuss, 1851), Marssonella -xycona (Reuss, 1860), Reussella szajnochae (Grzybowshi, 1896), and Stensioein pommerana (Brotzen, 1940), suggests bathyal depths for these deposits (Speijer, 1994). On the other hand, the presence of slump scars, slumps and brecciated beds indicates instability during deposition.

Within the Carche Formation, the Globotruncanita elevata Partial Range Zone to the lower part of the Gmusserina gansseri Interval Zone has been recognized (Fig. 6). Following the biochronostratigraphy of
Hardenbol et al. (1998), the age of the Carche Formation in the Sierra del Maigmó is early Campanian-early Maastrichtian.

As mentioned above, the outcrop of the Raspay Formation is very incomplete here. It consists mainly of marls of a distinct olive green colour and some beds of marly wackestones, both deposited in an environment that does not seem to differ significantly from that of the underlying unit. These marls have yielded planktic foraminifera of the Abathomphalus mayareensis Zone (late Maastrichtian).

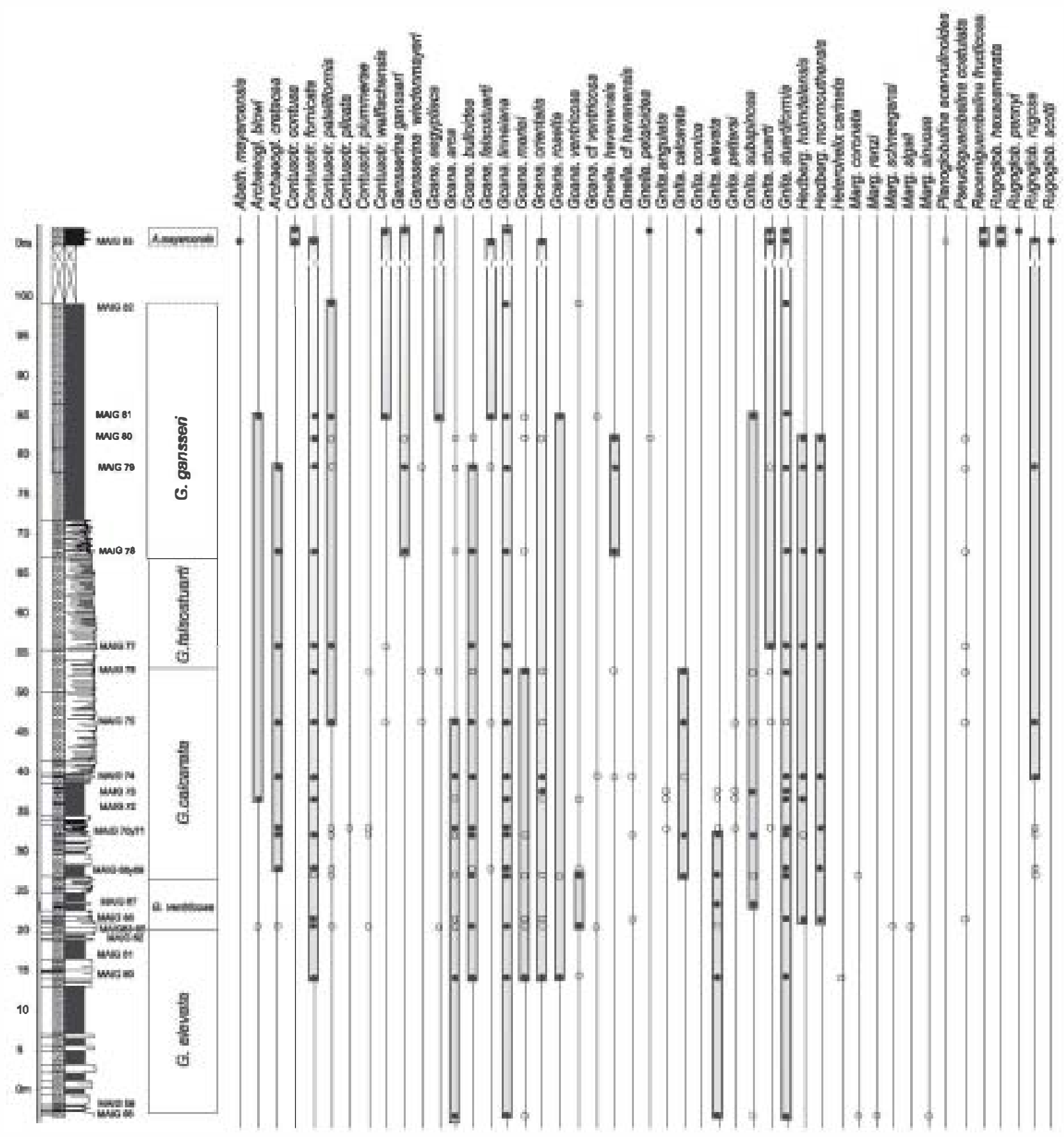

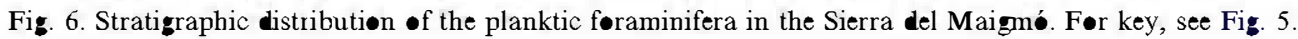


hemipelagic environment. The rich benthic foraminiferal assemblage, including Cibicidoides dayi (White, 1928),

The succession studied crops out extensively on the southern slope of the Sierra de Aixorta. The completeness of the succession, which includes the Carche and Raspay formations, and excellent exposure make this sierra an exceptional area to study the deposits. The results of previous work on this region can be found in Company et al. (1982).

The Carche Formation is $95 \mathrm{~m}$ thick and mainly consists of beige to white, sometimes reddish, limestones and marly limestones in decimetre-scale beds, with some centimetre-scale calcarenitic intercalations. The deposits are affected by abundant synsedimentary slumps that give quite a chaotic aspect to some portions of the section. This unit overlies a decimetre-scale debris flow bed that separates it from the underlying massive limestones of late Santonian age. The upper boundary is marked by conglomeratic deposits of debris flow type related to a "middle" Maastrichtian unconformity. In this unit the main facies are beige to white, sometimes reddish, wackestones rich in planktic foraminifera, ostracods, calcispheres, remains of inoceramids and echinoids and scarce benthic foraminifera; and red marly wackestones to marls, including a fossil association similar to that of the previous facies. Both facies can be highly to moderately bioturbated by Z••phyces structures. Between these deposits, two kind of intercalations can be identified: one consisting of beige to reddish, fine-grained, packstones to grainstones with abundant traction structures and with a fossil association similar to that of the main facies; and another formed by beige, coarse- to fine-grained, packstones to grainstones very rich in fragments of inoceramids, agglutinated benthic foraminifera and bivalves, and scarce planktic foraminifera.

The Carche Formation is here interpreted as having been deposited in a carbonate to mixed hemipelagic environment that occasionally received turbidite sediments and was intermittently under the influence of bottom currents. The presence of abundant slumps suggests instability during deposition. The Gløb•truncanita elevata Partial Range Zone to the lower part of the Gansserina gansseri Zone has been identified in the formation (Fig. 7), so that its estimated age is early Campanian-early Maastrichtian.

The Raspay Formation is $48 \mathrm{~m}$ thick and mostly composed of green marls that include some intercalations of greyish to greenish biomicrites, especially in the lowest few metres. This unit is overlain in apparent sedimentary continuity by greyish marly limestones that have been dated as early Palaeocene (Chacón, 2002). The deposits of this unit contain a rich assemblage of planktic foraminifera, calcispheres and ostracods, some benthic foraminifera, and scarce prisms of inoceramids. The Raspay Formation was deposited in a mixed
Cibicidoides hyphalus (Fisher, 1969), Coryphostoma incrassata (Reuss, 1851), Gaudryina pyranidata (Cushman, 1926), Marssonella exycona (Reuss, 1860), Reussella szajnochae (Grzybowski, 1896), and Stensioeina pommerana (Brotzen, 1940), points to deposition at almost an upper bathyal depth, according to the estimated depth ranges in Nyong and Olsson (1984).

Our biostratigraphic analysis of the Raspay Formation (Fig. 7) has allowed us to recognize the upper part of the Gansserina gansseri Zone, and the Abathomphalus mayaroensis Interval Zone. Accordingly, the formation in the Sierra de Aixorta is late Maastrichtian in age.

\subsection{Jijona-Buset-Tørremanzamas}

In the Jijona-Busot-Torremanzanas (JBT) area (Alicante province; Fig. 1), the Upper Cretaceous succession is characterized by pronounced and abrupt lateral changes in thickness and completeness. These changes were controlled by fault movements, which were very active during the late Cenomanian-early Turonian. Later, during the Coniacian-Maastrichtian, the sedimentation was controlled by the inherited topography (Ruig, 1992; Chacón, 2002; Martín-Chivelet et al., 2002). The study of four detailed stratigraphic sections and of several partial outcrops has allowed us to build the composite stratigraphic section shown in Fig. 8. The Campanian-Maastrichtian interval is represented in the area by the Aspe and Raspay formations.

The Aspe Formation is $7-35 \mathrm{~m}$ thick and shows a broadly rhythmic character, which results in an alternation of $0.1 \mathrm{~m}$ thick, usually white or cream, limestone beds and thin beds of reddish marly limestones to marls. The main facies are fine-grained wackestone and packstone biomicrites that contain a variable amount of fine siliciclastics, abundant planktic foraminifera, calcispheres and ostracods, scarce benthic foraminifera, and remains of inoceramids and echinoids. Bioturbation is moderate and mainly consists of small burrows, although Zøphyces structures are also present. The sedimentation of the Aspe Formation took place in a carbonate to mixed hemipelagic environment under uniform conditions. Typical rhythmic variations in the terrigenous content probably reflect high-frequency climate cycles (e.g., Zwan, 2002).

The planktic foraminiferal biozones identified in the formation in the JBT area are from the Globotruncmita elevata Partial Range Zone to the lower part of the Gansserina gansseri Zone (Fig. 8). This gives an early Campanian-early Maastrichtian age for the whole unit. All the biozones have been recognized only in the most subsided areas (as at Jijona Castle). In the outcrops on the elevated blocks (as at Torremanzanas, North Jijona, 

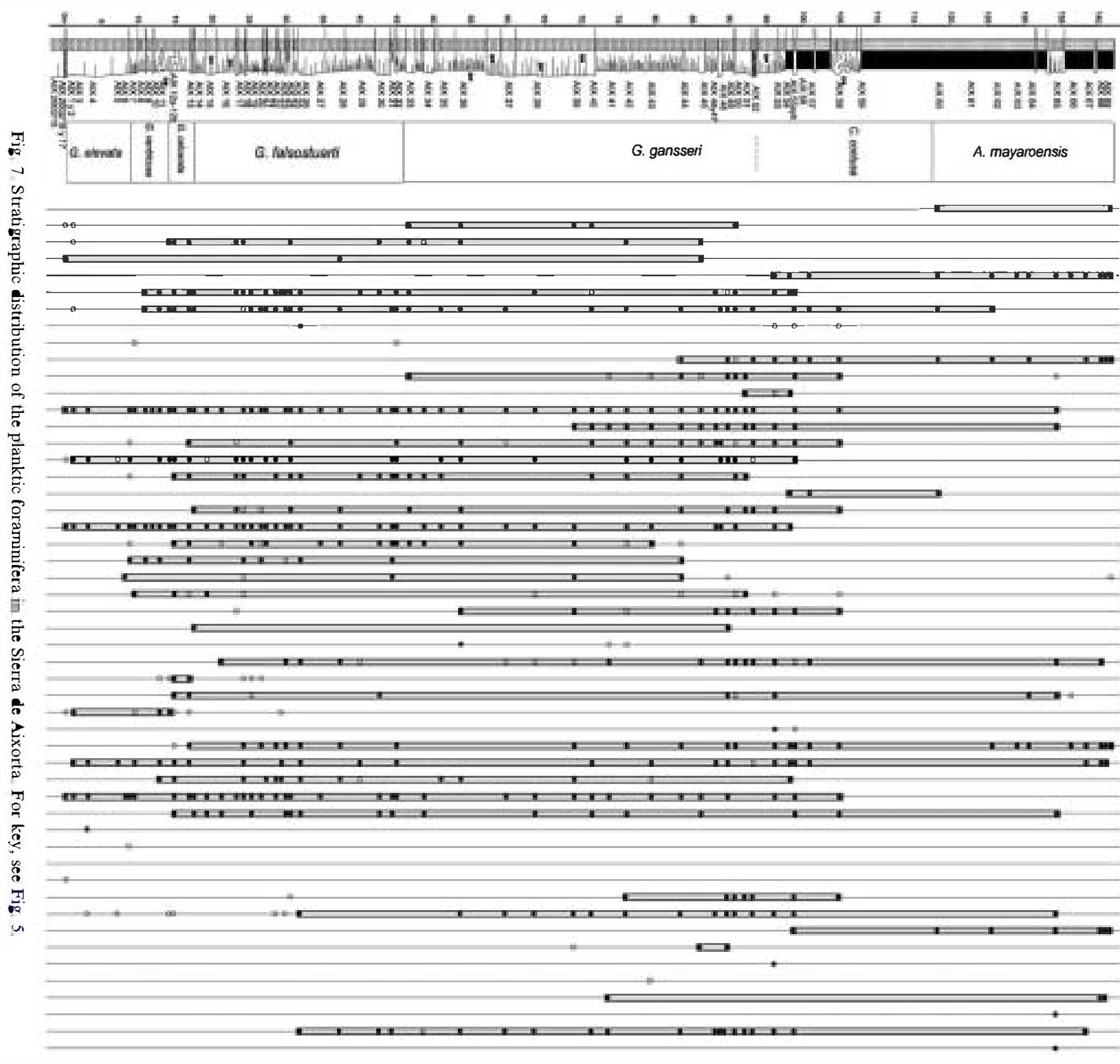

Abath. mayaroensis Archaeogl. blowi Archaeogl. cretacea Contusotruncana sp. Contusoti: contusa Contusotr. formicate
Contusotr. patelliformis Contusotr. plicate Contusotr. plummerae Contusotr. walfischensis Gansserina gansseri
Gansserina wiedenmayeri Globigerinelloides sp. Gnelloides. subcarinatus cana. aegypliaca Gcana. arca Gana. bulloides Gcana. dupeublei cana. linneiana Ocana. mariei Gcana. orientalis Gcana. Iosetta Gcana. ventricosa Gnella. havanensis Gnella. petaloidea Gnella. pschadae Gnite. angulata Gnita. calcarata Gnita. conica Gnita. elevata Gnita. petters Gnita. stuartiformis Gnita. subspinosa Hedberg. holmdelensis Hedberg. monmouthensis Marginotruncana sp. Marg. coronata Marg. schneegansi Marg. sigali

Planagobsins acarvulnoides Pseudoguembelina costulata Racemiguembelina fiucticosa Rugoglob. hexacamerata Rugoglob. macrocephala Rugoglob. milamensis 


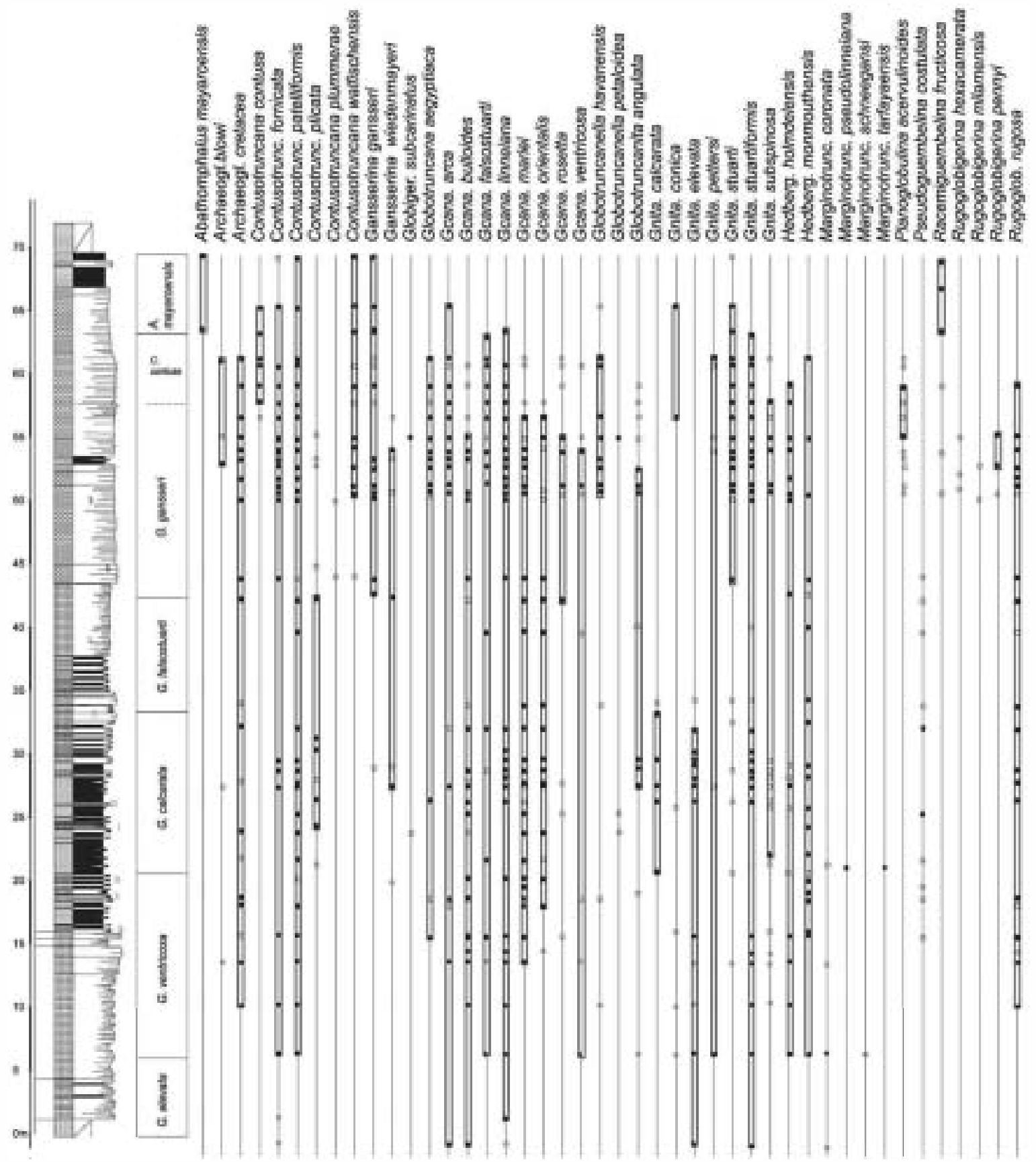

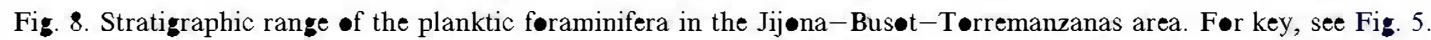

development of synsedimentary slumps. These reveal the existence of a short interval of instability before the deposition of the overlying Raspay Formation. The latter unit, which is much richer in fine siliciclastic sediment, mainly consists of olive green to reddish marls. It does not crop out completely anywhere in the JBT area; as a result only partial sections have been analysed. These yielded planktic foraminifera (Fig. 8) that allowed the recognition of, at Torremanzanas, the upper part of the Gansserina gansseri Zone and lower part of the Abathomphalus mayaroensis Interval Zone, and, near Busot, part of the Abathomphalus mayaroensis Zone.

\subsection{Aguas de Bus $\bullet$}

The section at Aguas de Busot is located in the nearby of the town of Busot, close to the $11 \mathrm{~km}$ marker post of the CV-773 local road. The succession analysed includes only part of the Aspe Formation, because the upper part of the unit is cut by an oblique fault. This partial section of the formation is $73 \mathrm{~m}$ thick and has 
a rhythmic aspect owing to a decimetre-scale alternation of beige to reddish limestones and marly limestones. The unit rests on upper Santonian white hemipelagic limestones.

Three main facies have been distinguished in the Aspe Formation: (1) beige to reddish wackestones that include abundant planktic and benthic foraminifera, ostracods, calcispheres, and fragments of inoceramids, echinoids and bivalves; (2) beige to red marly wackestones to marls; and (3) medium to fine-grained packstones to grainstones, with different traction structures that include fragments of inoceramids, echinoids and bivalves, planktic and deep-water benthic foraminifera, and calcispheres. All of these facies, but specially the first, can be moderately burrowed. Deposition took place in a carbonate to mixed hemipelagic environment at upper bathyal depths, as indicated by the benthic foraminiferal association, which includes Cibicidoides velascoensis (Cushman, 1925), Gaudryina pyramidata (Cushman, 1926), Gavelinella becariiformis (White, 1928), Marssonella •xycona (Reuss, 1860), Reussella szajn॰chae (Grzybowski, 1896), and Stensioeina pommerana (Brotzen, 1940). The deposits with packstone to grainstone textures are interpreted to have probably accumulated under the influence of bottom currents.

The planktic foraminifera (Fig. 9) have allowed recognition of the Globotruncanita elevata Partial Range Zone to the lower part of the Gansserina gansseri Interval Zone. Hence, the Aspe Formation here is early Campanian-early Maastrichtian in age.

\subsection{Aspe}

The Aspe outcrop is situated about $1 \mathrm{~km}$ to the south of the town of Aspe, in a triangular-shaped area bounded by the roads to Elche and Crevillente. This section, which gives its name to the formation, shows all its distinctive features, as well as those of the Raspay Formation. The stratigraphy of the section has been reported previously by Hillebrandt (1974).

The Aspe Formation, which has a minimum thickness of $55 \mathrm{~m}$ (the lower part is not exposed), is markedly rhythmic with alternating off-white to reddish limestone and marlstone beds $0.1-0.3 \mathrm{~m}$ thick. The upper boundary reflects an abrupt change in the depositional environment, erosive processes, the development of synsedimentary reverse faults (and related palaeohighs), and the presence of turbidite layers, slumps, and olistholiths (Chacón and Martín-Chivelet, 2001). The main facies are: (1) off-white to reddish wackestones, slightly to moderately burrowed, that are very rich in planktic foraminifera, calcispheres, and ostracods, and remains of inoceramids, echinoids, and bivalves, with scarce deep-water benthic foraminifera; (2) fine- to veryfine-grained packstones with a similar fossil assemblage; and (3) red marly wackestones to marls. The formation is interpreted to have been deposited in a carbonate to mixed hemipelagic environment. Again, the occurrence of fine- to very-fine-grained packstones suggests that the sea floor was probably under the influence of bottom currents.

From the lowest beds exposed to the top of the formation the Glob-truncanita calcarata Total Range Zone to the lower part of Gansserina gansseri Zone have been identified (Fig. 10). These biozones indicate an early late Campanian-early Maastrichtian age for these deposits.

The Raspay Formation is $50 \mathrm{~m}$ thick and mainly composed of green marls with some centimetre-scale greenish to greyish marly limestone beds and beige to ochre calcarenitic limestone beds. At the top it is bounded by an unconformity owing to erosive processes. Overlying this unconformity are latest Palaeocene-early Eocene marls and marly limestones.

The marls and marly limestones of the Raspay Formation contain a fossil association that consists of abundant planktic and deep-water benthic foraminifera, calcispheres, and remains of echinoids and inoceramids. The calcarenitic limestones are texturally medium- to coarse-grained packstones to grainstones with a fossil assemblage that contains abundant bioclasts of shallow water faunas (bivalve fragments, large benthic foraminifera, echinoids, red algae, bryozoans), some calcispheres and scarce planktic foraminifera. The formation has a chaotic aspect in this section because it is affected by abundant synsedimentary slumps. Deposition took place in a mixed hemipelagic environment that occasionally received the input of turbidites. The abundant synsedimentary deformation structures suggest instability during deposition. Based on the rich, deep-water benthic foraminiferal fauna, which includes Bolivinoides drace drac (Marsson, 1878), Cibicidoides velascoensis (Cushman, 1925), Coryphostoma incrassata (Reuss, 1851), Glob॰rotalites conicus (Carsey, 1926), Marssonella •xycona (Reuss, 1860), Neofiabellina rugosa (D'Orbigny), Nuttallinella ftorealis (White, 1928), Reussella szajnochae (Grzybowski, 1896), Sitella cushmani (Sandidge, 1932), and Stensioeina pommerana (Brotzen, 1940), an almost upper bathyal depth of deposition can be inferred (according to Morkhoven et al., 1986) from these beds.

The planktic foraminifera of the Raspay Formation (Fig. 10) allowed the recognition of the upper part of the Gansserina gansseri Zone, and the Abathomphalus mayaroensis Zone. Accordingly, a late Maastrichtian age is again indicated for the Raspay Formation.

\section{Discussion}

We have recognized seven biozones of planktic foraminifera for the uppermost Santonian-uppermost Maastrichtian succession examined in the south-east of 

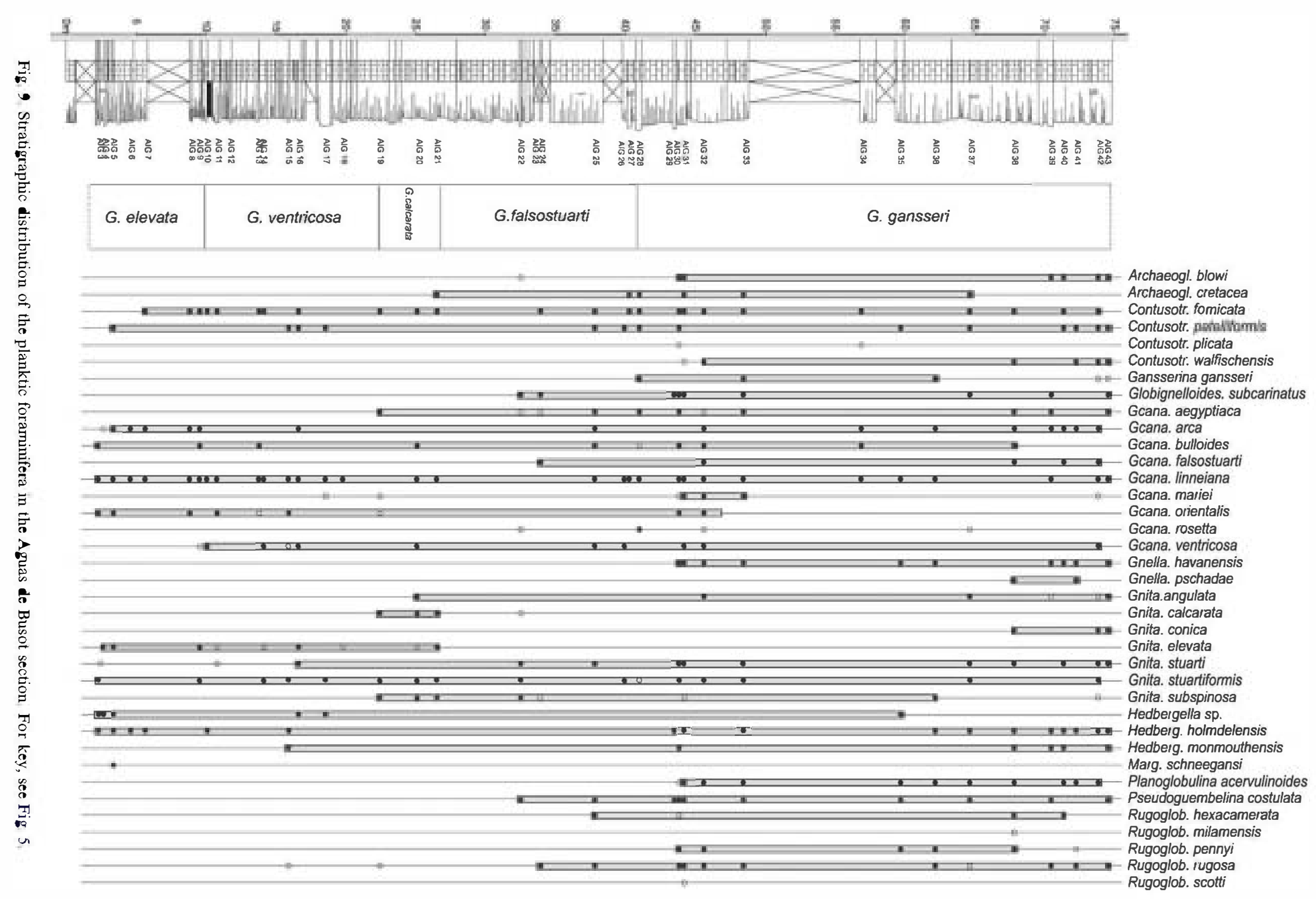


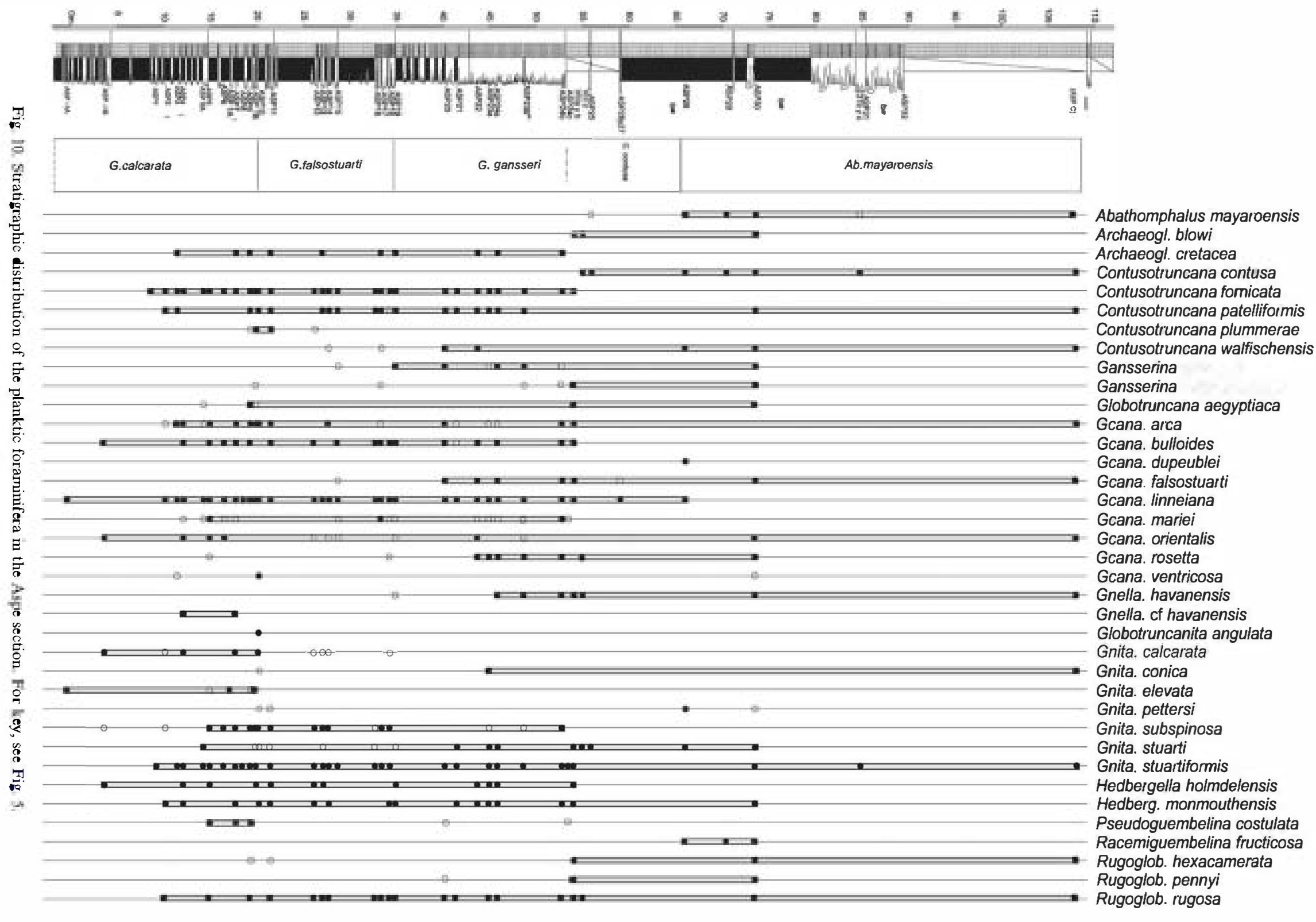


the Prebetic domain (Fig. 2). These are as follows, from base to top:

Dicarinella asymetrica Total Range Zone (uppermost part); definition as in Robaszynski and Caron (1995). In our sections we have recognized only the uppermost part of this biozone. It is characterized by the presence of species of the genera Contus@truncma, Gløb-truncana, Globotruncanita and Rugøglobigerina. These genera dominate the planktic foraminiferal assemblages through the rest of the Cretaceous succession. Local occurrences of planktic foraminifera are indicated in Fig. 5. The age of this uppermost part of the biozone is late Santonian (according to Hardenbol et al., 1998) to latest Santonian-earliest Campanian (according to Premoli Silva and Sliter, 1995; Robaszynski et al., 2000).

Globøtruncanita elevata Partial Range Zone, sensu Robaszynski and Caron (1995). Local occurrences of planktic foraminiferal species within this biozone are shown in Figs. 5-9. The estimated age for this biozone is early Campanian-early middle Campanian, after Hardenbol et al. (1998).

Gløb•truncana ventricesa Interval Zone; definition as in Robaszynski and Caron (1995). For local occurrences of the planktic foraminifera, see Figs. 5-9. The interpreted age for this biozone is, according to Hardenbol et al. (1998), middle Campanian.

Gløbtruncanita calcarata Total Range Zone; definition as in Robaszynski and Caron (1995). The occurrences of the planktic foraminiferal species within this biozone are shown in Figs. 5-10. Its age is early late Campanian, after Hardenbol et al. (1998).

Globøtruncana fals@stuarti Partial Range Zone; defined between the last occurrence (LO) of Gløb•truncanita calcarata (Cushman, 1927) and the first occurrence (FO) of the index species of the next biozone (Gansserina gansseri). The local occurrences of planktic foraminiferal species within this biozone are shown in Figs. 5-10. Its estimated age is late Campanian.

The Globotruncana falsøstuarti Zone was initially proposed for a global scale by Robaszynski et al. (1984). It was later revised and subdivided (Caron, 1985; Premoli Silva and Sliter, 1995) into the Globtruncanella havanensis Interval Zone (between the LO of G. calcarata and the FO of Globotruncana aegyptiaca) and the Globøtruncma ae gyptiaca Interval Zone (between the FO of G. aegyptiaca and the FO of Gansserina gansseri). In our study area, however, this subdivision cannot be applied because the FO of $G$. aegyptiaca is below the LO of $G$. calcarata. This also occurs in the Kalaat Senan section of central Tunisia (Robaszynski et al., 2000), indicating the biostratigraphic similarity of this area with the Prebetic region and the difference between these two areas and the Tercis section of south-west France.
Gansserina gansseri Zone; Interval Biozone from the FO of the index species Gansserina gansseri (Bolli, 1951) to the FO of the next biozone marker species (Abathomphalus mayaroensis), as defined in Robaszynski and Caron (1995). In this paper we have followed an informal subdivision of the Gansserina gansseri Zone into two parts, based on the first appearance of Contusøtruncana contusa (Cushman, 1926).

In the lower part, G. gansseri appears with Contusetruncuna walfischensis (Todd, 1970), Globøtruncanella pschadae (Keller, 1946), Plan॰globulina acervulinøides (Egger, 1899), Plummerita reicheli (Brönnimann, 1952), Rugoglobigerina milamensis (Smith and Pessagno, 1973), Rugoglobigerina pennyi (Brönnimann, 1952), and Rugeglobigerina scotti (Brönnimann, 1952). None of these species has been recognized in the previous biozones.

The upper part of the G. gansseri Zone is defined by the FO of Contusotruncana contusa (Cushman, 1926). Other marker species also first appear in this part of the zone. These are Gløbtruncana dupeublei (Caron, González Donoso, Robaszynski and Wonders, 1984), Racemiguembelina fructicosa (Egger, 1899), Rugoglobigerina macrocephala (Brönnimann, 1952), and Rugeglobigerina rotundata (Brönnimann, 1952). The upper part of the zone would be equivalent to the Contus truncana contusa/Racemiguembelina fructicesa Zone of Premoli Silva and Sliter (1995), defined at Gubbio (Italy), and also to the Contusetruncana contusa subzone of Robaszynski et al. (2000) in Tunisia.

The age of the $G$. gansseri Zone, according to Hardenbol et al. (1998), is latest Campanian to late (but not latest) Maastrichtian. By comparison with Premoli Silva and Sliter (1995), the upper part of this biozone (defined by the first appearance of $C$. contusa) would characterize the lower part of the upper Maastrichtian. A notable point is that in our sections the FO of Contusotruncana walfischensis is within the lower part of the G. gansseri Zone, much below the FO of $C$. contusa and $\boldsymbol{R}$. fructicesa. This differs from the situation in Tunisia where Robaszynski et al. (2000) found that $C$. contusa and $C$. walfischensis appear more or less at the same stratigraphic levels.

Abathomphalus mayaroensis Interval Zone; defined as in Robaszynski and Caron (1995). In our sections, A. mayareensis co-occurs with several species of Glob•truncema and Globotruncanita up to the Cretaceous/ Palaeogene boundary (Figs. 5-10). The estimated age for this highest biozone of the Cretaceous is late Maastrichtian-latest Maastrichtian.

Despite the differences explained above, the stratigraphic distribution of planktic foraminifera in this sector of the Betic Ranges is very similar to that of central Tunisia, and an equally similar succession of bioevents is recognized; hence the biozonation proposed 
by Robaszynski et al. (2000) for Kalaat Senan has been adopted for our study area.

However, comparison of this biozonation with that proposed by Odin (2001) and Odin et al. (2001) for the Campanian-Maastrichtian reference section of Tercis (south-west France) indicates significant differences. The biozonation of the Tercis succession comprises four zones: Gløb•truncana ventricosa/Gløbøtruncana rugosa, Radotruncana calcarata, Globotruncanella havanensis/ Rugeglobigerina rotundata, and Rug•globigerina scottil Contus trunceracentusa. It is based on a succession of bioevents that could not be recognized in our sections.

The FO of Globotruncana aegyptiaca at Tercis is confusing because it has been "diversely located by the different specialists" and "surprisingly, in levels below the Rd. calcarata-bearing deposits" (Odin et al., 2001, p. 391). The FO of G. aegyptiaca in the Prebetic area is below that in the Tercis section, since it may appear within the G. ventricesa Zone.

The FO of G. stuarti at Tercis is in the Gl. havanensis/ Rg. røtundata Zone, whereas in the Prebetic area it has been recognized within the G. calcarata Zone.

The FO of $\mathbf{R g}$. røtundata, which at Tercis is in the $G l$. havanensis/Rg. rotundat Zone, is higher in the sections of the Prebetic area, in the upper part of the Gansserina gansseri Zone.

At Tercis, the lower boundary of the Rg. scotti/C. contusa Zone is defined by the first co-occurrence of the two marker species. However, in the Prebetic sections the FO of $\mathbf{R g}$. scotti is often below that of $C$. contusa. Hence, the FO of $\mathbf{R g}$. scotti is within the lower to middle part of the $G$. gansseri Zone, whereas the FO of C. contusa is in the upper part of this zone.

To summarize, the lowest two biozones defined at Tercis, G. ventricesa/G. rugesa and Rd. calcarata, are probably equivalent to the G. ventricesa and G. calcarata biozones of the Prebetic area, respectively, but the other two biozones at Tercis, Gl. havanensis/Rg. rotundata and $\boldsymbol{R g}$. scoti/C. contusa, cannot be applied in our area.

Our results reveal that the succession of bioevents in the Prebetic area is quite similar to that of the Kalaat Senan region, but not comparable to the succession recognized in the Tercis area. The reasons for these discrepancies may reflect palaeogeographical or palaeoenvironmental differences, or difficulties with foraminiferal taxonomy. During the latest Cretaceous, the Prebetic and Kalaat Senan areas were on opposite margins of a closing Tethys Ocean (Fig. 1), in which the dispersion of pelagic forms was very effective. By contrast, the Tercis area, located on the Atlantic margin of Europe, had poor communication with the Tethys from the early Campanian onwards. A limited interchange of faunas with the southern domains could be expected. With respect to the palaeoenvironments, the Kalaat Senan and the Tercis sections were deposited in quite different settings: relatively deep hemipelagic to pelagic settings in the first case, shallower, outer shelf settings in the second. This could suggest a certain environmental control in the faunal assemblages. However, in the Prebetic sections we have studied, deposition evidently took place in a wide range of waterdepths, ranging from the outer platform (probably shallower than those of Tercis) to upper-middle bathyal (comparable to Kalaat Senan), and the planktic foraminifera in all of the sections have a similar biostratigraphic distribution patterns.

\section{Conclusions}

This paper presents the results of the first integrated sedimentological and biostratigraphical analysis of the Late Cretaceous (latest Santonian-latest Maastrichtian) open marine deposits of the eastern to southern part of the Prebetic Zone (Betic Ranges). Ten stratigraphic sections, reflecting depositional environments ranging from outer platform to bathyal, have been studied and correlated. This enabled the recognition of a succession of seven planktic foraminiferal biozones from the uppermost part of the Dicarinella asymetrica Zone to the Abathomphalus mayaroensis Zone. The G. gansseri Zone has been divided into two parts by the first appearance of Contusetruncana contusa. The planktic foraminiferal assemblages of this sector of the Betic Ranges have revealed that the succession of bioevents is quite similar to that of the Kalaat Senan region, but is significantly different from that of the reference section of Tercis. This suggests that further study is necessary in order to establish global correlations for this latest Santonian-latest Maastrichtian interval.

\section{Acknowledgements}

The work has been carried out with the financial support of the project REN 2001-1607/GLO of the Spanish Ministry of Science and Technology. Comments and suggestions by Malcom Hart and an anonymous referee are greatly appreciated. Thanks are extended to editor-in-chief, D.J. Batten, for his useful comments and editorial assistance.

\section{Ref erences}

Arz, J.A., Mølina, E., 2001. Planktic foraminiferal quantitative analysis acress the Campanian/Maastrichtian bøundary at Tercis (Landes, France). In: Odin, G.S. (Ed.), The Campanian-Maastrichtian Bøundary. Elsevier Science, Amsterdam, pp. 338-348.

Azéma, J., 1977. Etude géølogique des zønes externes de Cordillères Bétiques aux confins des provinces d'Alicante et de Murcie (Espagne). Unpublished $\mathrm{PhD}$ thesis, Université de Paris, Paris, $395 \mathrm{pp}$. 


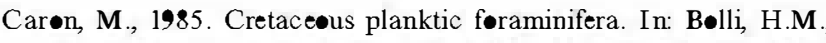
Saunders, J.B., Perch-Nielsen, K. (Eds.), Planktøn Stratigraphy. Cambridge University Press, Cambridge, pp. 17-670.

Chacøn, B., 2002. Las sucesiønes hemipelágicas del final del Cretácic e inici del Paleogen• en el SE de la Placa Ibérica: Estratigrafía de eventos y evolución de la cuenca. Unpublished $\mathrm{PhD}$ thesis, Universidad Complutense de Madrid, Madrid, $440 \mathrm{pp}$.

Chacon, B., Martín-Chivelet, J., 2001. Implicaciones tectosedimentarias de la discontinuidad estratigräica del Maastrichtiense medi• en Aspe (Prebétic $\bullet$ de Alicante). Revista de la S•ciedad Geølogica de España 14, 123-133.

Chacın, B., Martín-Chivelet, J. Unidades litøestratigräicas del

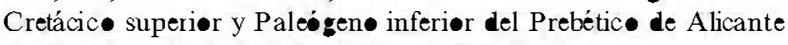
Revista de la Seciedad Geologica de España, in press.

Company, M., García-Hernández, M., Løpez Garride, A.C., Vera, J.A., Wilke, H., 1982. Interpretaciön genética y paleøge•grảica de las turbiditas y materiales redepøsitades del Sen॰niense superior en la Sierra de Aix •rta (Prebétic• Intern•, Prøvincia de Alicante). Cuadernøs de Geølogia Ibérica 8, 449-463.

Hardenbøl, J., Thierry, J., Farley, M.B., Jacquin, Th., Graciansky, P.-C., de, Vail, P.R., 1998. Cretaceous biøchrønstratigraphy. In Graciansky, P.-C., de, Hardenbøl, J., Jacquin, Th., Vail, P.R.

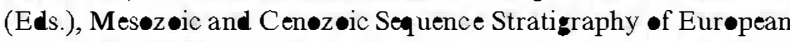

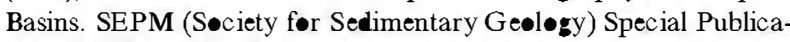

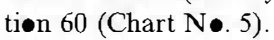

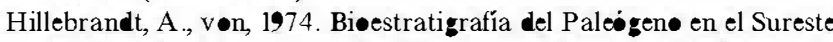
de España (Previncias de Murcia y Alicante). Cuadernes de Geølogia Ibérica 5, 135-153.

Leclerc, J., 1971. Etude géøløgique du massif du Maigm• et de ses abørds (Province d'Alicante, Espagne). Thèse 3ème cycle, Université de Paris, Paris, $128 \mathrm{pp}$.

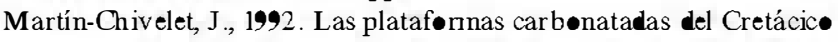
superiør de la Margen Bética (Altiplan• de Jumilla-Yecla, Murcia). Unpublished $\mathrm{PhD}$ thesis, Universidad Complutense de Madrid, Madrid, 899 pp.

Martín-Chivelet, J., 1994. Litøestratigrafía del Cretácic superiør del

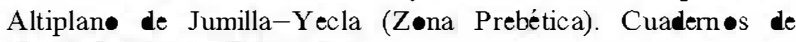
Geologia Ibérica 18, 117-173.

Martín-Chivelet, J,, 1995. Sequence stratigraphy of mix ed carbønate-siliciclastic platfonns developed in a tectonically active setting, Upper Cretaceous, Betic continental margin (Spain). Jøurnal •f Sedimentary Research B65, 235-254.

Martín-Chivelet, J., 1996. Late Cretaceus subsidence hist•ry of the Betic Continental Margin (Jumilla-Yecla regien, SE Spain). Tectøn๑physics 265, 191-211.

Martín-Chivelet, J., Berá stegui, X., R•sales, I., Vera, J.A., Vilas, L., Caus, E., Gräfe, K.-U., Segura, M., Puig, C., Mas, R., Røbles, S., Fløquet, M., Quesada, S., Ruiz-@rtiz, P.A., Fregenal-Martínez, M.A., Salas, R., García, A., Martín-Algarra, A., Arias, C., Meléndez, N., Chacın, B., Mølina, J.M., Sanz, J.L., Castrø, J.M., García-Herná ndez, M., Carenas, B., García-Hidalg•, J., Gil,

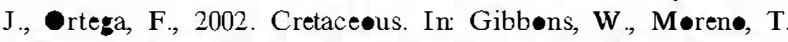

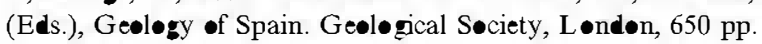

Mørkhøven, F.P.C.M., van, Berggren, W.A., Edwards, A.S., 1986.

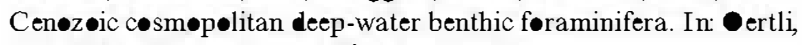
H.J. (Ed.), Elf Aquitaine, Mémøire 11, 421 pp.

Ny॰n to løwer Maastrichtian foraminifera in the N $\bullet$ rth American Basin

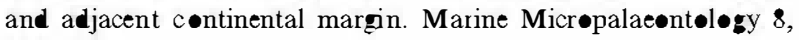
$437-477$.

-din, G.S., 2001. The Campanian-Maastrichtian bøundary: definitiøn at Tercis (Landes, SW France), principle, prøcedure, and prøp•sal. In: @din, G.S. (Ed.), The Campanian-Maastrichtian Bøundary. Elsevier Science, Amsterdam, pp. 820-833.

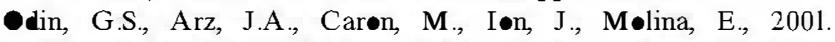
Campanian-Maastrichtian planktonic foraminifera at Tercis

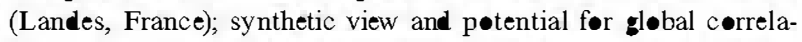
tion. In: Odin, G.S. (Ed.), The Campanian-Maastrichtian Bøundary. Elsevier Science, Amsterdam, pp. 379-395.

Premøli Silva, I., Sliter, W.V., 1995. Cretaceous planktønic foraminif-

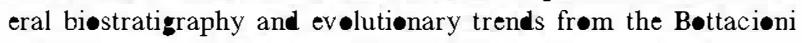

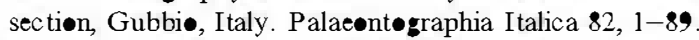

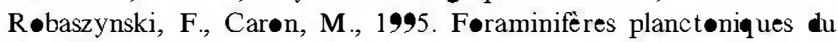
Crétacé: commentaire de la zønation Eurøpe-Méditerranée. Bulletin de la Søciété Géølogique de France 166, 681-692.

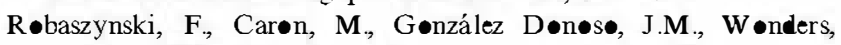
A.A.H., 1984. Atlas $\bullet$ Late Cretaceous gløbtruncanids. Revue de Micrøpalé ^nt•løgie 26, 145-305.

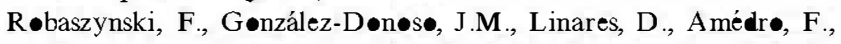
Carøn, M., Dupuis, C., Dhøndt, A.V., Gartner, S., 2000. Le Crétacé supérieur de la région de Kalaat Senan, Tunisie centrale.

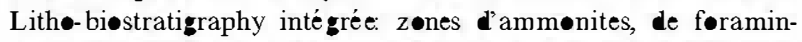
ifères planctøniques et de nann॰føssiles du Turønien supérieur au Maastrichtien. Bulletin des Centres de Recherches ExplørationProduction Elf Aquitaine 22, 359-490

Rødríguez Estrella, T., Granados y Granados, L.F., Saavedra, J.L., Gønzález, A., 1980. Estudi• geølogic en el sector de CarcheSalinas. Zøna prebética (Prøvincias de Murcia y Alicante). Bøletín de Geologia y Mineria $91,527-548$.

Ruig de M.J., 1992. Tectøn-sedimentary evølution of the Prebetic f $\bullet$ ld belt $\bullet$ Alicante (SE Spain). Unpublished $\mathrm{PhD}$ thesis, Free University, Amsterdam, $207 \mathrm{pp}$

Speijer, R.P., 1994. The late Paleocene benthic foraminiferal ex tinction as $\bullet$ bserved in the Middle East. Geoløgia Ultraiectina, Mededelingen van de Faculteit Aardwetenschappen, Universiteit Utrecht 124 , pp. $77-90$.

Vera, J.A., García-Hernández, M., Løpez Garride, A.C., C•mas, M.J., Ruiz-ortiz, P.A., Martín-Algarra, A., 1982. La C•rdillera Bética. El Cretácic de España. Universidad C•mplutense de Madrid, Madrid, pp. 515-631.

Ziegler, P.A., 1988. Evølution of the Arctic-N•rth Atlantic and the Western Tethys. American Assøciation of Petrøleum Geøløgists, Memøir 43, $198 \mathrm{pp}$.

Zwan, van der C.J., 2002. The impact •f Milankøvitch-scale climatic forcing on sediment supply. Sedimentary Geology 147, 271-294. 